\title{
Effects of Selected Plant Essential Oils on the Growth and Development of Mouse Preimplantation Embryos In Vivo
}

\author{
M. DOMARACKÝ, P. REHÁK, Š. JUHÁS, J. KOPPEL \\ Institute of Animal Physiology, Slovak Academy of Sciences, Košice, Slovak Republic \\ Received December 15, 2005 \\ Accepted February 22, 2006 \\ On-line available February 23, 2006
}

\begin{abstract}
Summary
Plant essential oils (EOs) have been reported to have health benefit properties and their preventive and therapeutic use in animals is expected to increase in the future. We evaluated the influence of five essential oils obtained from plant species which are known to have positive antimicrobial, antioxidative and anti-inflammatory effects - sage EO from Salvia officinalis L. (Lamiaceae), oregano EO from Origanum vulgare L. (Lamiaceae), thyme EO from Thymus vulgaris L. (Lamiaceae), clove EO from Syzygium aromaticum L. (Myrtaceae) and cinnamon EO from Cinnamomum zeylanicum Blume (Lauraceae) on the growth and development of mouse preimplantation embryos in vivo. Essential oils were added to commercial diet at concentrations of $0.25 \%$ for sage EO, thyme EO, clove EO, cinnamon EO and $0.1 \%$ for oregano EO, and fed to ICR female mice for 2 weeks ad libitum. Females were then mated with males of the same strain. Embryos obtained on Day 4 of pregnancy at the blastocyst stage were stained by morphological triple staining (Hoechst, PI, Calcein-AM) and evaluated using fluorescent microscopy. The effects of essential oils were estimated by the viability of embryos, number of nuclei and distribution of embryos according to nucleus number. Cinnamon EO significantly decreased the number of nuclei and the distribution of embryos according to nucleus number was significantly altered. Sage EO negatively influenced the distribution of embryos according to nucleus number. Clove and oregano EOs induced a significantly increased rate of cell death. Only thyme EO had no detectable effects on embryo development. In conclusion, none of the essential oils had any positive effect on embryo development, but some of them reduced the number of cells and increased the incidence of cell death.
\end{abstract}

\section{Key words}

Essential oils • Preimplantation embryo $\bullet$ Apoptosis $\bullet$ Mouse embryos

\section{Introduction}

A great number of plant species contain various chemical substances exhibiting health benefit properties, antioxidative, anti-inflammatory and antimicrobial effects. Their preventive and therapeutic use in animals is increasing. Following plant species exhibit these properties. Salvia officinalis, L. (Lamiaceae) is a perennial woody sub-shrub native to the Mediterranean area, used in the food-processing industry but also in the area of human health. It is well known for its fungistatic, virustatic and tannin-based antimicrobial properties. Antiinflammatory activities were reported to be caused by some constituents of plants such as triterpenes, oleanolic 
and ursolic acids, or the diterpene carnosol (Baricevic et al. 2001). Sage exhibits one of the strongest antioxidant activities among herbs (Santos-Gomes et al. 2002). Thymus vulgaris, L. (Lauraceae) is indigenous to Central and Southern Europe, and is now widely cultivated as a tea, spice and herbal medicine. Its leaves have been used as a stomachic, diuretic and urinary disinfectant. The anti-inflammatory effect of thyme has also been employed in traditional medicine. The main active ingredients of the essential oil (EO) are thymol and carvacrol, with antioxidative, antimicrobial and antifungal effects (Pina-Vaz et al. 2004, Proestos et al. 2005). Thymol also shows anti-aggregatory activity, strongly inhibiting platelet aggregation (Okazaki et al. 2002) which can be used in prevention of thrombosis and arteriosclerosis. Origanum vulgare L. (Lamiaceae) is a low-growing perennial native to the Mediterranean, Western Asia and North Africa. As a culinary and medicinal herb it was already well known in ancient Greece and Rome. As with the two previous species, oregano contains several phenolic compounds showing strong antioxidant activity (Matsuura et al. 2003). The main component of oregano oil, carvacrol, has strong bacteriostatic and bactericidal properties which predestine oregano for preventive and therapeutical use in animals (Mauch and Bilkei 2004). Cloves are dried unopened flower buds of Syzygium aromaticum L. (Myrtaceae), an evergreen tree in the myrtle family. The name comes from the French "clou" meaning nail. Twenty-two compounds have been identified in the extracts of clove buds, with eugenol and eugenyl acetate as the major aroma constituents. Their antioxidant activity has been proved and found comparable to that of the natural antioxidant, vitamin E (Lee and Shibamoto 2001). Eugenol is reported to have strong antifungal (Chami et al. 2004), anti-inflammatory (Dip et al. 2004) activity, and has been investigated for its potential anticarcinogenic effect (Dorai and Aggarwal 2004). It is a constituent of the clove EO, showing antibacterial effects (Burt and Reinders 2003). Cinnamomum zeylanicum Blume (Lauraceae) is the inner bark of a tropical evergreen tree and grows wild in Sri Lanka, Madagascar, India and Indochina. The essential oil shows antioxidant (Dhuley 1999), antibacterial (Friedman et al. 2004) antifungal (Wang et al. 2005) and some other therapeutic activities.

In general, the essential oils from the abovementioned plants are potentially useful mainly for their antibacterial, anti-inflammatory and antioxidant activities. Some of them are already used in human and veterinary medicine, however little is known about their influence on preimplantation embryos. The preimplantation phase of embryo development seems to be very sensitive and a number of compounds have been reported as toxic or lethal for embryos during the cleavage. Possible negative influences could have later consequences such as implantation failure, fetus death in the postimplantation period, and low litter size. The aim of our study was to investigate the effects of essential oils from cinnamon, clove, oregano, sage and thyme on the growth and development of mouse preimplantation embryos in vivo.

\section{Methods}

\section{Animals and treatment}

Female mice (ICR strain, Velaz, Prague, Czech Republic; 4 weeks old) were randomly divided into five experimental groups $(n=24)$ and one control group $(n=25)$. All animal experimentation was reviewed and approved by the Ethical Committee of the Institute of Animal Physiology. The main active compounds of the selected plant essential oils determined by gas chromatography (Calendula, Nova Lubovna, Slovak Republic) were as follows: Oregano EO - carvacrol (65\%); Cinnamon EO - eugenol (77 \%); Sage EO thujone (25\%), cineole (14\%), borneole (17\%); Thyme EO - thymol (24\%), p-cymene (48 \%); Clove EO eugenol $(85 \%)$. Essential oils were added to commercial rodent diet (Diet for laboratory mice and rats SPF, M1; Frantisek Machal, Ricmanice, Czech Republic) in $1 \%$ edible soya oil (Brölio, Germany) and fed to female mice for 2 weeks at the following concentrations: $0.25 \%$ clove EO; $0.25 \%$ cinnamon EO; $0.25 \%$ thyme EO; $0.25 \%$ sage EO and $0.1 \%$ oregano EO. $0.25 \%$ essential oil corresponds to a daily intake of $375 \mathrm{mg} / \mathrm{kg} ; 0.1 \%$ essential oil corresponds to $150 \mathrm{mg} / \mathrm{kg} /$ day. These doses of essential oils were tested in preliminary experiments on virgin females, which showed that average food intake and body weight gains were similar to the control animals. Control animals were fed on the diet with the vehicle only ( $1 \%$ edible soya oil). Feed and water were available ad libitum. Body weight of mice in all groups was evaluated on day 0,7 and 14 .

After the first 2 weeks, three females were placed with one male of the same strain for a maximum 
of eight days. Each morning the females were checked for the presence of a vaginal plug, which was taken as a Day 1 of pregnancy, and fertilized female was separated from the male. Unfertilized females were excluded from the experiment after 8 days. During that time all mice were fed ad libitum with a diet containing the tested essential oils or vehicle till Day 4 of pregnancy.

Fertilized mice: Oregano EO, n=14; Clove EO, $\mathrm{n}=17$; Cinnamon EO, $\mathrm{n}=17$; Thyme EO, $\mathrm{n}=15$; Sage EO, $\mathrm{n}=13$; Control, $\mathrm{n}=13$.

\section{Embryo recovery}

Females were killed by cervical dislocation on Day 4 of pregnancy. Embryos were recovered at the blastocyst stage on Day 4 of pregnancy separately from each animal by flushing the uterus using a flushingholding medium (FHM) (Lawits and Biggers 1993), and counted. The embryos were then transferred into $30 \mu \mathrm{l}$ drops of FHM and prepared for morphological triple staining.

\section{Morphological triple staining}

For morphological changes and cell viability assessment, embryos were stained with cell-permeant dye Hoechst 33342 (HO, $20 \mu \mathrm{g} / \mathrm{ml}$; Sigma-Aldrich; stains all cells), cell-impermeant dye propidium iodide (PI, $20 \mu \mathrm{g} / \mathrm{ml}$; Sigma-Aldrich; stains dead cells only), and cytoplasm was stained with Calcein AM (5 $\mu \mathrm{M}$; BioChemika, stains live cells only) for $40 \mathrm{~min}$ at $37{ }^{\circ} \mathrm{C}$. The embryos were then washed, sealed with coverslips and observed using fluorescence microscopy at $400 \times$ magnification (BX 51 Olympus, Japan).

The number of nuclei and corresponding morphological profile were assessed in all embryos: healthy nuclei, oval, with uniform Hoechst staining, or with visible chromosomes; condensed nuclei with dense Hoechst staining, smaller than normal nuclei; fragmented nuclei, in the process of karyorhexis or disintegrated into apoptotic bodies; disseminated fragments; and polar bodies. Healthy nuclei were counted as Hoechst normal nuclei, and condensed and fragmented nuclei as Hoechst damaged nuclei. Additional PI and Calcein staining was used for their following categorization (Fabian et al. 2004).

The following numbers of embryos were examined by morphological triple staining on Day 4: Oregano EO, $n=144$; Clove EO, $\mathrm{n}=143$; Cinnamon EO, $n=102$; Thyme EO, $\mathrm{n}=126$; Sage EO, $n=123$; Control, $\mathrm{n}=90$.

\section{Statistical analysis}

The results are expressed as mean values \pm S.D. The Chi-square test was used to detect differences in the preimplantation distribution of embryos according to nucleus number and the mean percentage of normal and dead cells. One-way ANOVA followed by Dunnett's test was used for the statistical analysis of total cell numbers of embryos and body weight changes of female mice. Values of $\mathrm{P}<0.05$ were considered as significant.

\section{Results}

The analysis of embryo growth and development influenced by plant essential oils evaluated by triple staining is shown in Table 1 . We examined number of nuclei and distribution of nuclei as parameters characterizing the growth and development of preimplantation embryos, and percentage of normal and dead cells (apoptotic or necrotic nuclei) to determine their viability.

The number of nuclei was significantly lower $(\mathrm{P}<0.01)$ in cinnamon essential oil-fed experimental animals, and the distribution of embryos according to nucleus number was also statistically significantly altered $(\mathrm{P}<0.001)$ in this group. We detected significant $(\mathrm{P}<0.05)$ changes in preimplantation distribution of embryos according to nucleus number after the sage essential oil administration. Other essential oils apparently did not influence preimplantation embryo growth. Viability of embryos was altered only minimally and appeared as an increase of cell death. Treatment with clove essential oil induced a significantly higher $(\mathrm{P}<0.01)$ percentage of dead cells $(0.8 \%)$ in comparison to $0.3 \%$ of dead cells in the control group. Oregano essential oil also significantly increased $(\mathrm{P}<0.05)$ the proportion of dead cells to $0.6 \%$. Only thyme essential oil had no detectable effects on embryo development.

Plant essential oils did not induce significant differences $(\mathrm{P}>0.05)$ in body weight of experimental animals (Table 2).

\section{Discussion}

Natural plant products have been used since ancient times and their use is now increasing. Some essential oils are known to have various health benefit 
Table 1. Analysis of the growth and development and cell death incidence in mouse preimplantation embryos obtained on Day 4 from ICR mice fed with diet containing selected plant essential oils, evaluated by morphological triple staining (Hoechst, PI, Calcein AM)

\begin{tabular}{|c|c|c|c|c|c|c|}
\hline & $\begin{array}{c}\text { Oregano } \\
\text { (Origanum } \\
\text { vulgare) }\end{array}$ & $\begin{array}{c}\text { Clove } \\
\text { (Syzygium } \\
\text { aromaticum })\end{array}$ & $\begin{array}{l}\text { Thyme } \\
\text { (Thymus } \\
\text { vulgaris) }\end{array}$ & $\begin{array}{c}\text { Cinnamon } \\
\text { (Cinnamomum } \\
\text { zeylanicum) }\end{array}$ & $\begin{array}{c}\text { Sage } \\
\text { (Salvia } \\
\text { officinalis) }\end{array}$ & Control \\
\hline & $0.1 \%$ & $0.25 \%$ & $0.25 \%$ & $0.25 \%$ & $0.25 \%$ & \\
\hline Number of used mice & 24 & 24 & 24 & 24 & 24 & 25 \\
\hline No. of pregnant mice & 14 & 17 & 15 & 17 & 13 & 13 \\
\hline Obtained embryos & 144 & 143 & 126 & 102 & 123 & 90 \\
\hline Number of nuclei (Ø) & $44.8 \pm 11.6^{\mathrm{NS}}$ & $44.8 \pm 12.8^{\mathrm{NS}}$ & $45.5 \pm 13.2^{\mathrm{NS}}$ & $38.7 \pm 11.3^{* *}$ & $44.7 \pm 9.9^{\mathrm{NS}}$ & $44.5 \pm 11.2$ \\
\hline$\% 1-8$ nuclei & 0.0 & 0.0 & 0.0 & 0.0 & 0.0 & 0.0 \\
\hline$\% 9-16$ nuclei & 0.7 & 0.0 & 1.6 & 1.0 & 0.0 & 0.0 \\
\hline$\% 17-32$ nuclei & 18.8 & 22.4 & 18.3 & 44.1 & 17.9 & 18.9 \\
\hline$\% 33-64$ nuclei & 79.2 & 71.3 & 77.0 & 53.9 & 82.1 & 75.6 \\
\hline$\%>65$ nuclei & $1.4^{\mathrm{NS}}$ & $6.3^{\mathrm{NS}}$ & $3.2^{\mathrm{NS}}$ & $1.0^{* * *}$ & $0.0^{*}$ & 5.6 \\
\hline Normal nuclei (\%) & 99.4 & 99.2 & 99.7 & 99.9 & 99.6 & 99.7 \\
\hline Dead cells (\%) & $0.6^{*}$ & $0.8^{* *}$ & $0.3^{\mathrm{NS}}$ & $0.1^{\mathrm{NS}}$ & $0.4^{\mathrm{NS}}$ & 0.3 \\
\hline
\end{tabular}

Footnotes: $\varnothing$ means \pm S.D.; Normal nuclei are defined as Hoechst normal, PI-, Calcein+; dead cells are defined as a) apoptotic nuclei Hoechst damaged, PI+/-, Calcein+ and b) secondary necrotic nuclei - Hoechst normal/damaged, PI+/-, Calcein-; statistical difference NS $(P>0.05),{ }^{*}(P<0.05),{ }^{* *}(P<0.01),{ }^{* * *}(P<0.001)$. The one-way ANOVA followed by Dunnett's test was used for the mean cell number of nuclei, and the Chi-square test for the distribution of embryo cell number and for the profile of cell death incidence.

Table 2. Analysis of weight changes in female mice fed with a diet containing selected plant essential oils two weeks before mating evaluated on Day 0, 7 and 14.

\begin{tabular}{|c|c|c|c|c|c|c|c|c|c|}
\hline & \multicolumn{3}{|c|}{ Oregano } & \multicolumn{3}{|c|}{ Clove } & \multicolumn{3}{|c|}{ Thyme } \\
\hline Day & $\mathbf{0}$ & 7 & 14 & $\mathbf{0}$ & 7 & 14 & $\mathbf{0}$ & 7 & 14 \\
\hline Body & 21.0 & 21.8 & 22.7 & 20.9 & 21.9 & 22.8 & 20.7 & 21.9 & 22.7 \\
\hline weight $(g)$ & $\pm 1.1^{\mathrm{NS}}$ & $\pm 1.2^{\mathrm{NS}}$ & $\pm 1.3^{\mathrm{NS}}$ & $\pm 1.1^{\mathrm{NS}}$ & $\pm 1.0^{\mathrm{NS}}$ & $\pm 1.4^{\mathrm{NS}}$ & $\pm 0.9^{\mathrm{NS}}$ & $\pm 1.2^{\mathrm{NS}}$ & $\pm 1.6^{\mathrm{NS}}$ \\
\hline Initial & 100 & 103.8 & 108 & 100 & 105 & 109 & 100 & 105.3 & 109 \\
\hline weight (\%) & \pm 5.4 & \pm 5.6 & \pm 5.5 & \pm 5.4 & \pm 4.8 & \pm 6.2 & \pm 4.4 & \pm 5.3 & \pm 7.1 \\
\hline & \multicolumn{3}{|c|}{ Cinnamon } & \multicolumn{3}{|c|}{ Sage } & \multicolumn{3}{|c|}{ Control } \\
\hline Day & $\mathbf{0}$ & 7 & 14 & $\mathbf{0}$ & 7 & 14 & $\mathbf{0}$ & 7 & 14 \\
\hline Body & 20.5 & 21.6 & 22.6 & 20.8 & 21.4 & 22.4 & 20.0 & 21.9 & 22.8 \\
\hline weight (g) & $\pm 1.2^{\mathrm{NS}}$ & $\pm 1.4^{\mathrm{NS}}$ & $\pm 1.5^{\mathrm{NS}}$ & $\pm 1.0^{\mathrm{NS}}$ & $\pm 1.1^{\mathrm{NS}}$ & $\pm 1.3^{\mathrm{NS}}$ & \pm 3.7 & \pm 1.3 & \pm 1.5 \\
\hline Initial & 100 & 105.3 & 110 & 100 & 102.7 & 108 & 100 & 109.5 & 114 \\
\hline weight (\%) & \pm 5.6 & \pm 6.7 & \pm 6.8 & \pm 4.8 & \pm 5.0 & \pm 5.6 & \pm 18.4 & \pm 6.0 & \pm 6.7 \\
\hline
\end{tabular}

Data are means \pm S.D.; the one-way ANOVA statistical difference ${ }^{N S}(P>0.05)$

properties, especially antibacterial, anti-inflammatory and antioxidative activities.

Recent studies show that they can influence every organ system. The reproductive system is not an exception. It is known that some plant extracts can exhibit their effects during the preimplantation development of embryos. We can divide these effects into three categories:

1. Primary effect - when plant extracts are mainly used in medicine to influence embryo growth and 
development. The example is Ruta graveolens L. (Rutaceae) used for the purposes of therapeutic and fertility regulation and as an abortifacient (Freitas et al. 2005). Four-day ingestion of Ruta aqueous extract given to superovulated mice resulted in a high proportion of abnormal embryos with diminished cell numbers.

2. Secondary effect - when plant extracts exhibit their health benefit properties in other organ system, but simultaneously they can influence also the reproduction and development of embryos. Extracts of Rosmarinus officinalis L. (Lamiaceae) are apparently not toxic for humans but they could have abortive effects. The administration of rosemary aqueous extract to pregnant rats during Days 1-6 of pregnancy increased the preimplantation embryo loss, although the difference was not significant (Lemonica et al. 1996). Maytenus ilicifolia Mart. (Celastraceae) is used in folk medicine particularly for stomach disorders, but it is also used as an abortifacient agent by South American women. One study (Montanari and Bevilacqua 2002) showed a significant decrease in the number of implantation sites and fetuses in female mice that received the extract (1000 $\mathrm{mg} / \mathrm{kg}$ ) between the first and third day of pregnancy, indicating that Maytenus ilicifolia caused embryonic loss before the implantation period. It is interesting to note that the effect of the extract was not uniform among the animals of the treated group; some females showed preimplantation losses and reabsorptions, having no fetuses at all, whereas in others no alterations in these parameters were noted.

3. The effect of overdosage of administered plant extracts (dose-dependence). They exhibit health benefit properties in a specific range of concentrations but they can cause alterations if this range is surpassed. This dose-dependence was observed in study presenting the possible embryotoxic effects of Coleus barbatus Benth. (Lamiaceae). A hydroalcoholic extract was administered to pregnant rats during the preimplantation period in increasing doses 220, 440 and $880 \mathrm{mg} / \mathrm{kg} /$ day (Almeida and Lemonica 2000). Only the highest dose (880 $\mathrm{mg} / \mathrm{kg} /$ day) induced delayed fetal development and an anti-implantation effect.

We examined the effect of oregano, clove, thyme, cinnamon and sage essential oils on the growth and development of mouse preimplantation embryos in vivo. To our knowledge there are no available studies describing the influence of these essential oils on preimplantation embryos. The examined essential oils are reported to exhibit mainly antioxidative and protective effects, but usually within a specific range of concentrations. If this range is surpassed they could have negative effects.

Elbetieha et al. (1998) studied the effects of 200, 400 and $800 \mathrm{mg} / \mathrm{kg}$ of Salvia fruticosa Mill. (Lamiaceae) aqueous extract on pregnant female rats during the preimplantation period. The ingestion of $800 \mathrm{mg} / \mathrm{kg}$ reduced the number of implantations and increased the number of resorptions in the pregnant females. In our experiment we used EOs in doses of $375 \mathrm{mg} / \mathrm{kg}$ daily, apart from oregano EO $(150 \mathrm{mg} / \mathrm{kg})$. However, it is impossible to compare literature data directly because of significant differences in experimental design including various types of plant extracts and their compositions. Vujosevic and Blagojevic (2004) demonstrated the antimutagenic properties of sage essential oil administered to mice in the dose range $25-50 \mu \mathrm{l} / \mathrm{kg}$. Suppression of the mutagenic effect of mitomycin $\mathrm{C}$ and decreased numbers of aberrant cells was observed. However the higher dose $100 \mu \mathrm{l} / \mathrm{kg}$ induced cytotoxic effects. This observation seems to be comparable to our results, where our average dose $375 \mathrm{mg} / / \mathrm{kg}$ fed to mice had no evident cytotoxic effects, but there were alterations in the embryo cell distribution compared to control animals.

We observed a significant increase of dead cells in preimplantation embryos due to the addition of clove or oregano essential oil. Despite the relatively low levels of embryo cell death in our experiment, they could potentially have physiological significance due to the lower sensitivity of the morphological staining used (in comparison with TUNEL assay).

A higher incidence of cell death $(\mathrm{P}<0.01)$ was observed after treatment with clove EO containing eugenol as the main active compound. Eugenol is classified as a suppressor of cell proliferation and growth factor expression, a down-regulator of antiapoptotic proteins and activator of apoptosis (Dorai and Aggarwal 2004). Furthermore, it was shown that eugenol is able to slow down the growth and cause the apoptotic changes in carcinoma cells (Aggarwal et al. 2004). This observation was confirmed by studies carried out on leukemia cells HL 60 (Okada et al. 2005, Yoo et al. 2005) and melanoma cells (Ghosh et al. 2005).

Developmental toxicity of isoeugenol was reported by George et al. (2001). In their study pregnant rats received isoeugenol $(250,500$ or $1000 \mathrm{mg} / \mathrm{kg})$ on 
gestational days 6 through 19. The highest dose 1000 $\mathrm{mg} / \mathrm{kg} /$ day caused a decrease in maternal body weight gain (7-9 \% in comparison to controls), intrauterine growth retardation and skeletal defects in fetuses. It could be hypothesized that eugenol can inhibit processes related to the intensive cleavage of embryonic cells. It is interesting to note that eugenol is also the major active compound in cinnamon EO, but we observed rather different effects of cinnamon and clove EO on preimplantation embryo development. Cinnamon EO also contains cinnamaldehyd, which has been reported to have a strong antiproliferative effect and is also able to induce generation of reactive oxygen species in cells $(\mathrm{Wu}$ et al. 2004). Our results show that the addition of cinnamon EO induced a significant $(\mathrm{P}<0.01)$ decrease in the average number of nuclei, closely connected with the significantly altered distribution of embryo cell numbers, while changes in the cell death rate were not significant. All these observations may be connected with the antiproliferative effects of cinnamaldehyd. It is probable that these influences are dose-related and that higher doses of cinnamon EO could induce a significant increase of dead cell proportions.

The principal components of oregano and thyme EOs are thymol and carvacrol. In oregano EO they represent around 78-82\% of the total oil (Botsoglou et al. 2002). Besides the known antioxidative properties of both plant species, oregano is also used as a natural feed additive supporting growth and reproductive performance. Oregano has been reported to increase the farrowing rate and decrease the stillbirth rate in sows (Allan and Bilkei 2005). However, with our experimental design we found no significant changes due to oregano or thyme EOs in preimplantation development.

In conclusion, our results show that none of the examined essential oils positively influenced mouse preimplantation embryo growth and development after their addition to the maternal diet. Some of them negatively influenced embryonal growth and viability. One of the possible reasons for this could be the relatively high concentration of administered EOs, but in any case the used concentrations correspond well with the generally recommended doses for prophylaxis in animal husbandry. On the other hand, the positive effects of essential oils might be better evident in stressful conditions such as infection or oxidative stress.

\section{Acknowledgements}

This work was supported by Science and Technology Assistance Agency under the contract No. APVT-51015404, by the Slovak Academy of Sciences (VEGA 2/3065/23) and by the State Program of Science and Development (SP 51/028 09 00/028 09 06).

\section{References}

AGGARWAL BB, TAKADA Y, OOMMEN OV: From chemoprevention to chemotherapy: common targets and common goals. Expert Opin Investig Drugs 13: 1327-1338, 2004.

ALLAN P, BILKEI G: Oregano improves reproductive performance of sows. Theriogenology 63: 716-721, 2005.

ALMEIDA FCG, LEMONICA IP: The toxic effects of Coleus barbatus B. on the different periods of pregnancy in rats. J Ethnopharmacol 73: 53-60, 2000.

BARICEVIC D, SOSA S, DElla LOGGIA R, TUBARO A, SIMONOVSKA B, KRASNA A, ZUPANIC A: Topical anti-inflammatory activity of Salvia officinalis L. leaves: the relevance of ursolic acid. J Ethnopharmacol 75: 125-132, 2001.

BOTSOGLOU NA, FLOROU-PANERI P, CHRISTAKI E, FLETOURIS DJ, SPAIS AB: Effect of dietary oregano essential oil on performance of chickens and on iron-induced lipid oxidation of breast, thigh and abdominal fat tissues. Br Poult Sci 43: 223-230, 2002.

BURT SA, REINDERS RD: Antibacterial activity of selected plant essential oils against Escherichia coli O157:H7. Lett Appl Microbiol 36: 162, 2003.

CHAMI N, CHAMI F, BENNIS S, TROUILLAS J, REMMAL A: Antifungal treatment with carvacrol and eugenol of oral candidiasis in immunosuppressed rats. Braz J Infect Dis 8: 217-226, 2004.

DHULEY JN: Anti-oxidant effects effects of cinnamon (Cinnamomum verum) bark and greater cardamom (Amomum subulatum) seeds in rats fed high fat diet. Indian J Exp Biol 37: 238-42, 1999.

DIP EC, PEREIRA NA, FERNANDES PD: Ability of eugenol to reduce tongue edema induced by Dieffenbachia picta Schott in mice. Toxicon 43: 729-735, 2004. 
DORAI T, AGGARWAL BB: Role of chemopreventive agents in cancer therapy. Cancer Lett 215: 129-140, 2004.

ELBETIEHA A, AL-HAAMOND MH, ALKOFAHI A, BATAINEH H: Reproductive toxicity potentials of Salvia fruticosa (Labiatae) in rats. J Ethnopharmacol 61: 67-74, 1998.

FABIAN D, ILKOVA G, REHAK P, CZIKKOVA S, BARAN V, KOPPEL J: Inhibitory effect of IGF-1 on induced apoptosis in mouse preimplantation embryos cultured in vitro. Theriogenology 61: 745-755, 2004.

FREITAS TG, AUGUSTO PM, MONTANARI T: Effect of Ruta graveolens L. on pregnant mice. Contraception 71: 74-77, 2005.

FRIEDMAN M, HENIKA PR, LEVIN CE, MANDRELL RE: Antibacterial activities of plant essential oils and their components against Escherichia coli O157:H7 and Salmonella enterica in apple juice. J Agric Food Chem 52: 6042- 6048, 2004.

GEORGE JD, PRICE CJ, MARR MC, MYERS CB, JAHNKE GD: Evaluation of the developmental toxicity of isoeugenol in Sprague-Dawley (CD) rats. Toxicol Sci 60: 112-120, 2001.

GHOSH R, NADIMINTY N, FITZPATRICK JE, ALWORTH WL, SLAGA TJ, KUMAR AP: Eugenol causes melanoma growth suppression through inhibition of E2F1 transcriptional activity. $J$ Biol Chem 280: 5812$5819,2005$.

LAWITS JA, BIGGERS JD: Culture of preimplantation embryos. In: Guide to Techniques in Mouse Development. Methods in Enzymology. PM WASSARMAN, ML De PHAMPHILIS (eds), Academic Press, San Diego, 1993, pp. 153-164.

LEE KG, SHIBAMOTO T: Antioxidant property of aroma extract isolated from clove buds [Syzygium aromaticum (L.) Merr. et Perry]. Food Chem 74: 443-448, 2001.

LEMONICA IP, DAMASCENO DC, DI-STASI LC: Study of the embryotoxic effects of an extract of rosemary (Rosmarinus officinalis L.). Braz J Med Biol Res 29: 223-227, 1996.

MATSUURA H, CHIJI H, ASAKAWA C, AMANO M, YOSHIHARA T, MIZUTANI J: DPPH radical scavengers from dried leaves of oregano (Origanum vulgare). Biosci Biotechnol Biochem 67: 2311-2316, 2003.

MAUCH C, BILKEI G: Strategic application of oregano feed supplements reduced sow mortality and improves reproductive performance - a case study. J Vet Pharmacol Ther 27: 61-63, 2004.

MONTANARI T, BEVILACQUA E: Effect of Maytenus ilicifolia Mart. on pregnant mice. Contraception 65: 171-175, 2002.

OKADA N, HIRATA A, MURAKAMI Y, SHOJI M, SAKAGAMI H, FUJISAWA S: Induction of cytotoxicity and apoptosis and inhibition of cyclooxygenase-2 gene expression by eugenol-related compounds. Anticancer Res 25: 3263-3269, 2005.

OKAZAKI K, KAWAZOE K, TAKAHASHI Y: Human platelet aggregation inhibitors from thyme (Thymus vulgaris L.). Phytother Res 16: 398-399, 2002.

PINA-VAZ C, GONCALVES-RODRIGUES AG, PINTO E, COSTA-DE-OLIVIERA S, TAVARES C, SALGUEIRO L, CAVALEIRO C, GONCALVES MJ: Antifungal activity of thymus oils and their major compounds. $J$ Eur Acad Dermatol Venerol 18: 73-78, 2004.

PROESTOS C, CHORIANOPOULOS N, NYCHAS GJ, KOMAITIS M: RP-HPLC analysis of the phenolic compounds of plant extracts. Investigation of their antioxidant capacity and antimicrobial activity. $J$ Agric Food Chem 53: 1190-1195, 2005.

SANTOS-GOMES PC, SEABRA RM, ANDRADE PB, FERNANDES-FERREIRA M: Phenolic antioxidant compounds produced by in vitro shoots of sage (Salvia officinalis L.). Plant Sci 162: 981-987, 2002.

VUJOSEVIC M, BLAGOJEVIC J: Antimutagenic effects of extracts from sage (Salvia officinalis) in mammalian system in vivo. Acta Vet Hung 52: 439-443, 2004.

WANG SY, CHEN PF, CHANG ST: Antifungal activities of essential oils and their constituents from indigenous cinnamon (Cinnamomum osmophloeum) leaves against wood decay fungi. Bioresour Technol 96: 813-818, 2005.

WU SJ, NG LT, LIN CC: Effects of vitamin $\mathrm{E}$ on the cinnamaldehyde-induced apoptotic mechanism in human PLC/PRF/5 cells. Clin Exp Pharmacol Physiol 31: 770, 2004. 
YOO CB, HAN KT, CHO KS, HA J, PARK HJ, NAM JH, KIL UH, LEE KT: Eugenol isolated from the essential oil of eugenia caryophyllata induces a reactive oxygen species-mediated apoptosis in HL-60 human promyelocytic leukemia cells. Cancer Lett 225: 41-52, 2005.

\section{Reprint requests}

Juraj Koppel, Institute of Animal Physiology, Slovak Academy of Sciences, Šoltésovej 4-6, 04001 Košice, Slovak Republic. Fax: +421 55 7287842. E-mail: koppel@saske.sk 